\title{
Clinical Manifestations, Blood Serotonin Level, Electroencephalography and Brain Magnetic Resonance Imaging in Autistic Children
}

\author{
Mohammad Abdel hadi
}

\begin{abstract}
The Aim of the Study: Identification of the common clinical manifestations and types of autism in children Identification if there is a correlation between the clinical manifestations and blood serotonin level, electroencephalography (EEG) changes, and Brain Magnetic Resonance Imaging (MRI) changes.

Subjects Methods: Two groups of children were included in this study :The first group included autistic patients of various The second group included the control group: All children (cases and controls) were subjected to the following: History \&examinations, measurement of plasma level of serotonin, neurophysiological assessment by using conventional EEG Brain magnetic resonance imaging (MRI)

Results: The study was carried out on 22 autistic children and 10 healthy control children matched for age and sex. Highly statistically significant difference between study groups as regard EEG abnormality which higher in patients than control group $P<0$.01. Statistically significant difference between the studied children in frontal horn widths $(P<0.05)$.(Autistics were higher than controls). Statistically significant difference among study groups in diameter of inner table of clavrium $(P<0.05)$.

Conclusion: Hyperactivity are a significant co-morbid conditions associated with autism. There is a positive correlation between epilepsy and severity of autism. There is high blood serotonin level in about one-third of autistic children with positive correlation between high serotonin level and severity of autistic features. There is a positive correlation between brain MRI measurement abnormalities and severity of autism.

Fathi, m., afifi, shora, y., darwish, Hazem, h., el-khalegy, tarek, i., Menecie, Kamel, M., ewedi, mohammad Abdel hadi, mohey el-din Tharwat.,

Department of Neurology, Al-Azhar university, Cairo. Department of Clinical pathology, Al-azhar university, Cairo

Conflict of interest: Non

Financial grant : Non
\end{abstract}

\section{Introduction}

Autism is a neurodevelopmental disorder with a range of clinical presentations. These presentations vary from mild to severe and are referred to as autism spectrum disorders. The most common clinical sign of autism spectrum disorders is social interaction impairment, which is associated with verbal and non-verbal communication deficits and stereotyped and repetitive behaviors (Zilbovicius M. et al., 2006).

There is no one specific cause of autism. Research has focused on whether chemical imbalances, differences in the brain, genetics, or problems with the immune system play a role in causing the disorder (Rutter M., 2005) .

Abnormal Electroencephalography (EEG) is obtained in 13\% to 83\% of autistic children, the varying percentage rate between the studies are probably explained by the different criteria used for the clinical diagnosis of autism (Chugani D., 2002).

Magnetic Resonance Imaging (MRI) may be helpful as part of a neurological assessment in the presence of focal neurological findings or severe developmental delay, but it cannot be used for diagnosis of Autism (Salmond H. et al., 2003).

Two of the most consistently observed biological findings in autism are increased serotonin levels in the blood and immunological abnormalities (including auto reactivity with tissues of the central nervous system) (Germano E. et al., 2006)

The Aim of the Study:

1. Identification of the common clinical manifestations and types of autism in children.

2. Identification if there is a correlation between the clinical manifestations and blood serotonin level, electroencephalography (EEG) changes, and Brain Magnetic Resonance Imaging (MRI) changes. These may help in early detection and early intervention of the autistic disorder.

Subjects: 
- The study was carried out during the period between beginning of January 2007 and end of August 2008.

Two groups of children were included in this study:

- The first group included autistic patients of various types attending the Pediatric Neurology Clinic at AlAzhar University Hospitals.

- The second group included the control group which had children with no medical or neuropsychiatric illness, and matched with age and sex with patient group.

\section{Inclusion Criteria:}

- The included children were fullfilling the criteria for autistic disorder according to the DSM-IV TR (American Psychiatric Association, 2000).

- Apparent healthy children (regarding motor and hearing function).

- Age from 2 to 13 years. No gross or major MRI brain abnormalities (like apparent brain congenital abnormalities, tumors, infections, or hypoxic/ ischemic insult)

\section{Exclusion Criteria:}

1. Patients with specific pervasive developmental disorder syndromes as Rett's syndrome and childhood disintegrative disorder.

2. Focal or generalized neurological abnormalities.

3. Children with chronic medical disorders as (Hypertension, chest diseases, gastrointestinal tract disorders or endocrinal diseases)

\section{Methods:}

All children (cases and controls) were subjected to the following:

1. Prenatal, Developmental and Neuropsychiatric History.

2. General and Neuropsychiatric Examinations.

3. Complete assessment of hearing.

4. Diagnosis and evaluation of autism was based on :

I. The criteria listed in 4th edition of diagnostic and statistical manual of mental disorder Text Revision (DSM-IV-TR).

II. Childhood Autism Rating Scale (CARS).

According to CARS, the patients were divided into 2 groups:

- Group 1: mild to moderate autism or (high functioning autism) [CARS score form 30 to less than 39].

- Group 2: severe autism or (low functioning autism) [CARS score from 39 to 60].

5. Measurement of plasma level of serotonin.

6. Neurophysiological assessment by using conventional EEG

7. Brain magnetic resonance imaging (MRI) for:

A. Detection of any minor structural abnormalities associated with autism.

B. MRI measurements of certain brain areas: (Frontal horm, caudate nucleus, inner table of clavrium and corpus callosum).

\section{Statistics.}

All data are collected, summarized, presented and analyzed by using an appropriate statistical package program (SPSS version, 13). All quantitative data are summarized by mean and standard deviation. Qualitative data are summarized by number and percentage. Test of significance for qualitative data is chi square Test of significance for quantitative data for 2 groups is $t$ test, for more than two groups is $F$ test, Post hoc test (LSD) used to detect differences between groups (Armitage P., 1989).

\section{Results}

The study was carried out on 22 autistic children and 10 healthy control children matched for age and sex. The children were subdivided into 3 groups:

Group 1: included 8 cases with mild to moderate autism or "High functioning autism".

Group 2: included 14 cases with severe autism or "Low functioning autism".

Group 3: control group which included 10 healthy children.

Table (1): Demographic data of study groups

\begin{tabular}{|c|c|c|c|}
\hline .0 & $\begin{array}{l}\text { Group (1) } \\
\mathrm{N}=8 \\
\text { Mild } \\
\text { moderate } \\
\text { Autism }\end{array}$ & $\begin{array}{l}\text { Group (2) } \\
\mathrm{N}=14 \\
\text { Sever } \\
\text { Autism }\end{array}$ & $\begin{array}{l}\text { Group (3) } \\
\mathbf{N}=10 \\
\text { Control }\end{array}$ \\
\hline
\end{tabular}




\begin{tabular}{|c|c|c|c|c|c|c|c|c|}
\hline (1) Age & $\begin{array}{l}\mathbf{X}^{\prime} \\
7.8\end{array}$ & $\begin{array}{r}\text { (SD) } \\
\text { ( } 3)\end{array}$ & $\begin{array}{l}\mathbf{X}^{\prime} \\
(\mathbf{S D}) \\
7.2 \\
(3.9)\end{array}$ & \pm & $\begin{array}{l}\begin{array}{l}\mathbf{X}^{\prime} \\
(\mathbf{S D})\end{array} \\
7.1 \\
(3.5)\end{array}$ & $\begin{array}{l} \pm \\
\pm\end{array}$ & $\begin{array}{l}\text { F } \\
\text { test } \\
0.10 \\
9\end{array}$ & $\begin{array}{l}\mathrm{P}= \\
0.999 \\
\mathrm{P} \quad> \\
0.05 \\
\mathrm{NS}\end{array}$ \\
\hline (2) Sex & $\mathbf{N}$ & $\%$ & $\begin{array}{l}\mathbf{N} \\
\%\end{array}$ & & $\begin{array}{l}\mathbf{N} \\
\%\end{array}$ & & \multirow[t]{6}{*}{$\begin{array}{l}\mathrm{X}^{2} \\
1.6\end{array}$} & \multirow{6}{*}{$\begin{array}{l}\mathrm{P}= \\
0.435 \\
\mathrm{P} \\
0.05 \\
\mathrm{NS}\end{array}$} \\
\hline Male & 7 & 87.5 & $\begin{array}{l}10 \\
71.4\end{array}$ & & $\begin{array}{l}6 \\
60\end{array}$ & & & \\
\hline Female & 1 & 12.5 & $\begin{array}{l}4 \\
28.6\end{array}$ & & $\begin{array}{l}4 \\
40\end{array}$ & & & \\
\hline $\begin{array}{l}\text { (3) } \\
\text { Family } \\
\text { history }\end{array}$ & $\mathbf{N}$ & $\%$ & $\begin{array}{l}\mathbf{N} \\
\%\end{array}$ & & $\begin{array}{l}\mathbf{N} \\
\%\end{array}$ & & & \\
\hline Yes & 2 & 25 & $\begin{array}{l}0 \\
0\end{array}$ & & $\begin{array}{l}0 \\
\mathrm{o}\end{array}$ & & & \\
\hline No & 6 & 75 & $\begin{array}{l}14 \\
100\end{array}$ & & $\begin{array}{l}10 \\
100\end{array}$ & & & \\
\hline $\begin{array}{l}\text { (4) } \\
\text { Consan } \\
\text { guinity }\end{array}$ & $\mathbf{N}$ & $\%$ & $\begin{array}{l}\mathbf{N} \\
\%\end{array}$ & & $\begin{array}{l}\mathbf{N} \\
\%\end{array}$ & & \multirow[t]{4}{*}{$\begin{array}{l}\mathrm{X}^{2} \\
1.4\end{array}$} & \multirow{4}{*}{$\begin{array}{l}\mathrm{P} \quad= \\
0.019 \\
\mathrm{P} \quad> \\
0.05 \\
\mathrm{NS}\end{array}$} \\
\hline No & 4 & 50 & $\begin{array}{l}12 \\
85.7\end{array}$ & & $\begin{array}{l}10 \\
100\end{array}$ & & & \\
\hline $\begin{array}{l}1^{\text {st }} \\
\text { degree }\end{array}$ & 1 & 12.5 & $\begin{array}{l}2 \\
14.3\end{array}$ & & $\begin{array}{l}0 \\
0\end{array}$ & & & \\
\hline $\begin{array}{l}2^{\text {nd }} \\
\text { degree }\end{array}$ & 3 & 37.5 & $\begin{array}{l}0 \\
0\end{array}$ & & $\begin{array}{l}0 \\
0\end{array}$ & & & \\
\hline
\end{tabular}

This table shows no statistically significant difference between study groups as regard age, sex, positive family history and consanguinity $(\mathrm{P}>0.05)$.

Table (2): Classification of autistic children according to their CARS Score.

\begin{tabular}{|l|l|l|}
\hline CARS score & Number (22) & \% \\
\hline $\begin{array}{l}\text { Mild to moderate autism } \\
\text { "High functioning" } \\
\text { "Group 1" }\end{array}$ & 8 & 36.4 \\
\hline $\begin{array}{l}\text { Severe autism } \\
\text { "Low functioning autism" } \\
\text { "Group 2" }\end{array}$ & 14 & 63.6 \\
\hline
\end{tabular}

Table (3): Comparisons of medical history among study groups

\begin{tabular}{|c|c|c|c|c|c|c|c|c|}
\hline \multirow[b]{2}{*}{ Pregnancy } & \multicolumn{2}{|c|}{$\begin{array}{l}\text { Group (1) } \\
\mathrm{N}=8 \\
\text { Mild Autism }\end{array}$} & \multicolumn{2}{|c|}{$\begin{array}{l}\text { Group (2) } \\
\mathrm{N}=14 \\
\text { Sever Autism }\end{array}$} & \multicolumn{2}{|c|}{$\begin{array}{l}\text { Group (3) } \\
\mathrm{N}=10 \\
\text { Control }\end{array}$} & 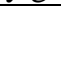 & \multirow{2}{*}{$\mathrm{P}=0.464$} \\
\hline & $\mathbf{N}$ & $\%$ & $\mathbf{N}$ & $\%$ & $\mathbf{N}$ & $\%$ & $\mathrm{X}^{2}$ & \\
\hline - Normal & 4 & 50 & 11 & 78.5 & 9 & 90 & 7.6 & $P>0.05$ \\
\hline - Twins & 2 & 25 & 1 & 7.2 & 0 & 0 & & \\
\hline - Health problem & 2 & 25 & 2 & 14.3 & 1 & 10 & & \\
\hline Delivery & $\mathbf{N}$ & $\%$ & $\mathbf{N}$ & $\%$ & $\mathbf{N}$ & $\%$ & $\mathrm{X}^{2}$ & $\mathrm{P}=0.785$ \\
\hline - Normal & 4 & 50 & 10 & 71.4 & 7 & 70 & 1.1 & $P>0.05$ \\
\hline - C.S & 3 & 37.5 & 3 & 21.4 & 3 & 30 & & NS \\
\hline - ventouse delivery & 1 & 12.5 & 1 & 7.2 & 0 & 0 & & \\
\hline Birth weight & $\mathbf{N}$ & $\%$ & $\mathbf{N}$ & $\%$ & $\mathbf{N}$ & $\%$ & $\mathrm{X}^{2}$ & $\mathrm{P}=0.885$ \\
\hline - Normal & 6 & 75 & 13 & 92.8 & 8 & 80 & 1.3 & $P>0.05$ \\
\hline - Low & 2 & 25 & 1 & 7.2 & 2 & 20 & & NS \\
\hline Type of feeding & $\mathbf{N}$ & $\%$ & $\mathbf{N}$ & $\%$ & $\mathbf{N}$ & $\%$ & $\mathrm{X}^{2}$ & $\mathrm{P}=0.181$ \\
\hline - Breast & 6 & 75 & 13 & 92.8 & 10 & 100 & 3.4 & $P>0.05$ \\
\hline - Formula & 2 & 25 & 1 & 7.2 & 0 & 0 & & NS \\
\hline History of Epilepsy & $\mathbf{N}$ & $\%$ & $\mathbf{N}$ & $\%$ & $\mathbf{N}$ & $\%$ & $\mathrm{X}^{2}$ & $\mathrm{P}=0.0112$ \\
\hline -Yes & 4 & 50 & 8 & 57.1 & 0 & 0 & 8.8 & $P<0.05$ \\
\hline - No & 4 & 50 & 6 & 42.9 & 10 & 100 & & $\mathrm{~S}$ \\
\hline
\end{tabular}

This table shows no statistically significant difference between study groups as regard medical history except for history of epilepsy which is higher among sever autism than both mild and healthy one

Table (4): First observed symptom for the autistic children):

\begin{tabular}{|l|l|l|}
\hline & $\begin{array}{l}\text { Number } \\
(\mathbf{2 2})\end{array}$ & $\mathbf{\%}$ \\
\hline Language defect & 15 & 68.2 \\
\hline Social defect & 5 & 22.7 \\
\hline Behavioral defect & 2 & 9.1 \\
\hline
\end{tabular}

Table (5): Blood serotonin levels of the studied children

\begin{tabular}{|l|l|l|l|}
\hline Blood Serotonin & Group (1) & Group (2) & Group (3) \\
\hline
\end{tabular}




\begin{tabular}{|c|c|c|c|c|c|c|c|}
\hline & & & & & & & \\
\hline & $\mathbf{N}$ & $\%$ & $\mathbf{N}$ & $\%$ & $\mathbf{N}$ & $\%$ & \multirow{3}{*}{$\begin{array}{l}\mathrm{X}^{2} \\
3.3 \quad \mathrm{P}= \\
0.183 \\
(\mathrm{P}>0.05) \\
\mathrm{NS}\end{array}$} \\
\hline Normal & 6 & 75 & 9 & 64.3 & & 100 & \\
\hline Increased & 2 & 25 & 5 & 35.7 & 0 & 0 & \\
\hline
\end{tabular}

Table (6): Comparison of EEG findings among study groups

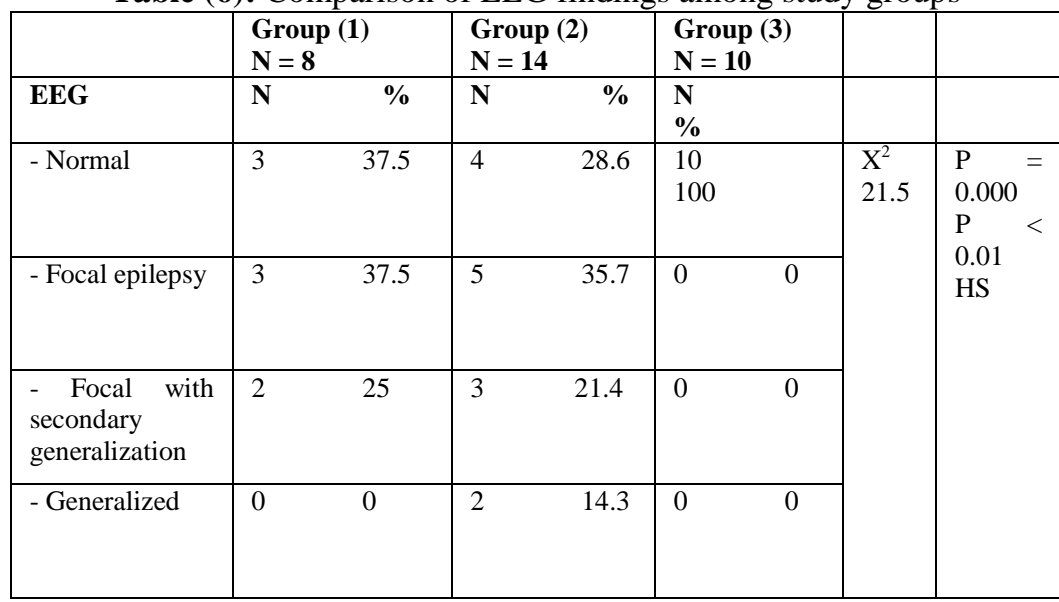

This table revealed highly statistically significant difference between study groups as regard EEG abnormality which higher in patients than control group $\mathrm{P}<0.01$

Table (7): Comparison of MRI measurements of frontal horn width among study groups

\begin{tabular}{|l|ll|lll|ll|l|l|}
\hline & \multicolumn{2}{|l|}{$\begin{array}{l}\text { Group (1) } \\
\mathbf{N = 8}\end{array}$} & \multicolumn{2}{|l|}{$\begin{array}{l}\text { Group (2) } \\
\mathbf{N}=\mathbf{1 4}\end{array}$} & \multicolumn{2}{l|}{$\begin{array}{l}\text { Group (3) } \\
\mathbf{N}=\mathbf{1 0}\end{array}$} & F-test & \\
\hline & $\mathbf{X}^{\prime}$ & (SD) & $\mathbf{X}^{\prime}$ & (SD) & $\mathbf{X}^{\prime}$ & (SD) & & \\
\hline $\begin{array}{l}\text { FH } \\
\text { width }\end{array}$ & 3.4 & $(0.31)$ & 3.4 & $(0.7)$ & 2.9 & $(0.3)$ & 3.7 & $\begin{array}{l}\mathrm{P}=0.35 \\
\mathrm{P}<0.05 \mathrm{~S}\end{array}$ \\
\hline
\end{tabular}

This table shows statistically significant difference between the studied children in frontal horn widths $(\mathrm{P}<$ 0.05).(Autistics were higher than controls).

Table (8): Comparison of MRI measurement of caudate nuclei among study groups

\begin{tabular}{|c|c|c|c|c|c|c|c|c|}
\hline & \multicolumn{2}{|c|}{$\begin{array}{l}\text { Group (1) } \\
\mathrm{N}=8\end{array}$} & \multicolumn{2}{|c|}{$\begin{array}{l}\text { Group (2) } \\
\mathrm{N}=14\end{array}$} & \multicolumn{2}{|c|}{$\begin{array}{l}\text { Group (3) } \\
\mathbf{N}=\mathbf{1 0}\end{array}$} & \multirow[t]{2}{*}{ F-test } & \\
\hline & & (SD) & & (SD) & & (SD) & & \\
\hline $\begin{array}{l}\text { - Length of } \\
\text { right caudate }\end{array}$ & 2.1 & (0.3) & 2.2 & (0.3) & 1.9 & $(0.2)$ & 2.8 & $\begin{array}{l}P=0.073 \\
P>0.05 \\
N S\end{array}$ \\
\hline $\begin{array}{l}\text { - Length of left } \\
\text { caudate }\end{array}$ & 2 & (0.3) & 2.1 & $(0.3)$ & 1.9 & $(0.2)$ & 1.1 & $\begin{array}{l}P=0.322 \\
P>0.05 \\
\text { NS }\end{array}$ \\
\hline $\begin{array}{l}\text { Width of } \\
\text { right caudate }\end{array}$ & 1.09 & $(0.1)$ & 1.09 & $(0.1)$ & 0.96 & $(0.12)$ & 3.1 & $\begin{array}{l}P=0.056 \\
P>0.05 \\
N S\end{array}$ \\
\hline $\begin{array}{l}\text { - Width of Left } \\
\text { caudate }\end{array}$ & 1.06 & $(0.12)$ & 1.05 & (0.19) & 0.93 & $(0.14)$ & 2 & $\begin{array}{l}P=0.148 \\
P>0.05 \\
N S\end{array}$ \\
\hline $\begin{array}{l}\text { - Area of right } \\
\text { caudate }\end{array}$ & 2.3 & $(0.51)$ & 2.4 & (0.45) & 1.9 & $(0.4)$ & 3.7 & $\begin{array}{l}\mathrm{P}=0.35 \\
\mathrm{P}<0.05 \mathrm{~S}\end{array}$ \\
\hline $\begin{array}{l}\text { - Area of left } \\
\text { caudate }\end{array}$ & 2.1 & (0.6) & 2.2 & $(0.47)$ & 1.7 & $(0.2)$ & 3.1 & $\begin{array}{l}\mathrm{P}=0.58 \\
\mathrm{P}>0.05 \\
\mathrm{NS}\end{array}$ \\
\hline $\begin{array}{l}\text { - (IC) } \\
\text { Inter caudate } \\
\text { distance }\end{array}$ & 0.75 & $(0.3)$ & 0.70 & $(0.2)$ & 0.84 & $(0.12)$ & 2.9 & $\begin{array}{l}P=0.069 \\
P>0.05 \\
\text { NS }\end{array}$ \\
\hline
\end{tabular}

This table shows no statistically significant difference between MRI measurement of caudate areas except Rt caudate area $(\mathrm{P}<0.05)$ but measurement is higher in autistic than control group except intercaudate distance which is lower in autistics than controls. 
Table (9): Comparison of MRI measurements of frontal horn width among study groups

\begin{tabular}{|c|c|c|c|c|c|}
\hline & $\begin{array}{l}\text { Group (1) } \\
N=8\end{array}$ & $\begin{array}{l}\text { Group (2) } \\
N=14\end{array}$ & $\begin{array}{l}\text { Group (3) } \\
N=10\end{array}$ & F-test & \\
\hline & $\mathbf{X}^{\prime} \quad(\mathbf{S D})$ & $\begin{array}{l}\mathbf{X}^{\prime} \\
\text { (SD) }\end{array}$ & $\mathbf{X}^{\prime} \quad$ (SD) & & \\
\hline $\begin{array}{l}\text { FH } \\
\text { width }\end{array}$ & $3.4 \quad(0.31)$ & $\begin{array}{l}3.4 \\
(0.7)\end{array}$ & $2.9 \quad(0.3)$ & 3.7 & $\begin{array}{l}\mathrm{P}=0.35 \\
\mathrm{P}<0.05 \mathrm{~S}\end{array}$ \\
\hline
\end{tabular}

This table shows statistically significant difference between the studied children in frontal horn widths $(\mathrm{P}<$ 0.05).(Autistics were higher than controls).

Table (10): Comparison of MRI measurement of inner table of clavrium among study groups.

\begin{tabular}{|c|c|c|c|c|c|}
\hline & $\begin{array}{l}\text { Group (1) } \\
\mathbf{N}=8\end{array}$ & $\begin{array}{l}\text { Group (2) } \\
\mathrm{N}=14\end{array}$ & $\begin{array}{l}\text { Group (3) } \\
\mathbf{N}=10\end{array}$ & F-test & \\
\hline & $\mathbf{X}^{\prime} \quad(\mathbf{S D})$ & $\begin{array}{ll}\mathbf{X}^{\prime} & \text { (SD) }\end{array}$ & $\begin{array}{ll}\mathbf{X}^{\prime} & (\mathbf{S D})\end{array}$ & & \\
\hline $\begin{array}{l}\text { IT } \\
\text { Inner table } \\
\text { of clavrium }\end{array}$ & $13.2(0.69)$ & $12.8 \quad(0.69)$ & $12.5 \quad(0.58)$ & 2.1 & $\begin{array}{l}\mathrm{P}=0.139 \\
\mathrm{P}<0.05 \mathrm{~S}\end{array}$ \\
\hline
\end{tabular}

This table shows statistically significant difference among study groups in diameter of inner table of clavrium (P $<0.05)$.

Table (11): Comparison of MRI measurements of corpus callosum among study groups:

\begin{tabular}{|l|l|l|l|l|l|}
\hline & $\begin{array}{l}\text { Group (1) } \\
\mathbf{N = 8}\end{array}$ & $\begin{array}{l}\text { Group (2) } \\
\mathbf{N = 1 4}\end{array}$ & $\begin{array}{l}\text { Group (3) } \\
\mathbf{N = 1 0}\end{array}$ & F-test & \\
\hline $\mathbf{X}^{\prime} \quad$ (SD) & $\begin{array}{l}\mathbf{X}^{\prime} \\
\text { (SD) }\end{array}$ & $\begin{array}{l}\mathbf{X}^{\prime} \\
\text { (SD) }\end{array}$ & & \\
\hline $\begin{array}{l}\text { (1)LCC } \\
\text { Length of } \\
\text { collosum }\end{array}$ & $5.9 \quad(0.33)$ & $\begin{array}{l}6.1 \\
(0.5)\end{array}$ & $\begin{array}{l}6.6 \\
(0.56)\end{array}$ & 5.2 & $\begin{array}{l}\mathrm{P}=0.011 \\
\mathrm{P}<0.05 \mathrm{~S}\end{array}$ \\
\hline (2) Genu & $0.81 \quad(0.2)$ & $\begin{array}{l}0.82 \\
(0.2)\end{array}$ & $\begin{array}{l}1.03 \\
(0.14)\end{array}$ & 3.1 & $\begin{array}{l}\mathrm{P}=0.56 \\
\mathrm{P}>0.05 \\
\mathrm{NS}\end{array}$ \\
\hline $\begin{array}{l}\text { (3)Splenium } \\
\text { part }\end{array}$ & $0.88(0.12)$ & $\begin{array}{l}0.82 \\
(0.19)\end{array}$ & $\begin{array}{l}0.88 \\
(0.16)\end{array}$ & 0.446 & $\begin{array}{l}\mathrm{P}=0.645 \\
\mathrm{P}>0.05 \\
\mathrm{NS}\end{array}$ \\
\hline $\begin{array}{l}\text { (5)Posterior } \\
\text { part }\end{array}$ & $0.5(0.11)$ & $\begin{array}{l}0.46 \\
(0.1)\end{array}$ & $\begin{array}{l}0.58 \\
(0.1)\end{array}$ & 3.4 & $\begin{array}{l}\mathrm{P}=0.047 \\
\mathrm{P}<0.05 \mathrm{~S}\end{array}$ \\
\hline
\end{tabular}

This table shows no statistically significant difference between the 3 groups in corpus callosum measurements except length of corpus callosum and anterior part in which there were decreased values in autistics than controls $(\mathrm{P}<0.05)$.

\section{Discussion}

In the present study, the autistic children's mean age at recognition of first symptom was 24 months. Two studies found the average age of recognition to be 14.9 months and 18.3 months (Volkmar F. et al., 1985; Siegel B. et al., 1998). Other studies, found the average age of symptoms arousing concern was 19.1 months using the Autism Diagnostic Interview (Lord C. et al., 1994; DeGiacoma A. and Fombonne E., 1998).

These studies suggest that parents first notice differences in their children fairly early, given the complexities of actual diagnosis (Daley T., 2004).

Age of first manifestation of autism is a matter of some dispute (Bailey A. et al., 1996). Probably the model age where parents become seriously concerned about autism is at two years of age when language delay becomes a concern (Adrien J. et al., 1992). However, several retrospective studies show that parents noticed abnormalities by 12 months of age or earlier. Examples are: Lack of anticipation for being picked up, eye to eye 
gaze for social signaling, joint attention, reaching for a familiar person and imitating other people's actions, e.g., waving good bye or clapping hands. Retrospective studies of home movies at 9-12 months and at first birthday by Osterling J. and Dawson G., (1994) document these findings.

In the present study, the male to female ratio was 3.4:1.

Folstein S. and Rosen - Sheidley B. (2001) found the male to female ratio of idiopathic autism is 4$10: 1$.

One of the consistent findings in autism is the male predominance, with ratios ranging from 3:1 to 10:1 in high functioning autism (Gillberg C. and Coleman M., 2000; Baron-Cohen S., 2002; Fombonne E., 2003; Yeargin-Allsopp M. et al., 2003).

The preponderance of males suggests an X-Linked disorder, and recent genome-wide screens by 2 separate groups have found evidence of linkage to the $\mathrm{X}$ chromosome, but the data are inconsistent (Liu J. et al., 2001; Shao Y. et al., 2002).

In the present study, the rate of autistic children with history of autism in the family was $9 \%$. In the study of Hanan H. (2006), the positive family history was $17.5 \%$ for families that have one child with autism; there is an increased risk of having another child with autism. This recurrence risk is estimated to be about $4 \%$ which is greater than that found in families that do not have a child with autism (Gillberg C., 1998).

In our study we found a considerable consanguinity rate of $22.27 \%$ and this is in agreement with the result of Hanan H., (2006), where the consanguinity was estimated as $20 \%$.

Consanguinity is not often reported as a risk factor in western countries, since consanguineous marriages are banned (Filipek P. et al., 1999).

Twin studies reported 60\% concordance for classic autism in monozygotic (MZ) twins versus none in Dizygotic twins. The higher MZ concordance supporting genetic inheritance as the predominant causative agent (Muhle R. et al., 2004). In the present study, three of the autistic group children were identical twins, 2 (25\%) from group 1 (high functioning autism) and 1 (7.2\%) from group 2 (low functioning autism).

In our study, maternal health problems during pregnancy were found in 4 cases (18.18\%) (2 from group 1 and 2 from group 2); included one mother had oligohydraminos, two anaemia and one pyelonephritis.

In the study of Hanan H., (2006), 25\% of mothers of the autistic children developed health problems during pregnancy including toxaemia of pregnancy, gestational diabetes, hypertention, medical conditions and obstetrical conditions. .

In this study, 14 (63.6\%) of the autistic children were delivered normally, while 6(27.3\%) by caesarean section and 2 (9.1\%) by ventouse "instrumental delivery". In the study of HananH., (2006), 47.5\% of the autistic children were delivered normally while $52.5 \%$ were delivered by cesarean section.

In the present study, $3(13.64 \%)$ of the autistic children were low birth weight. In the study of Hanan H., (2006), (12.5\%) needed incubator care and (10\%) were either premature or developed neonatal convulsions.

A reduced fetal nutrient supply might be a consequence of poor placental function, and an outcome of a sub-optimal placental nutrient supply is exposure of the fetus to excess glucocorticoids, which act to restrict fetal growth and to programme permanent changes in the neural, cardiovascular, endocrine and metabolic systems. The role of poor placental function and sub-optimal placental nutrient supply in the pathogenesis of autism should be further investigated (Bertram C. and Hanson M., 2002).

In the present study, $19(86.36 \%)$ of the autistic children were breast fed and $3(13.64 \%)$ formula fed, and this is in agreement with the result of the study of Hanan H., (2006).

Social level was found to have no effect on the incidence of autism (Fombonne E., 1999; Larsson H. et al., 2005). In the present study, (13.64\%) of the mothers were illiterate and only (4.56\%) of fathers also illiterate, $(63.63 \%)$ of the mothers were a level less than university and about the same percentage for fathers, $(22.73 \%)$ of mothers were a level of university or higher and $(31.81 \%)$ of fathers were the same level.

In the present study, the size of family of autistic children ranged from 3 to 7 , and as regard birth order $(50 \%)$ of autistic children were born further on. The result was statistically insignificant and this is in agreement of the result of the study of Hanan H., (2006).

In the present study, $12(54.54 \%)$ of the autistic children were epileptic, 4 out of $8(50 \%)$ from group 1 (High Functioning Autism), 8 out of 14 (57.1\%) from group 2 (Low Functioning Autism). So, in our study, epilepsy was found higher among low functioning group than high functioning group.

Epilepsy occurs in 10-30\% of individuals with autism. This association was mentioned in the first description of autism by Kanner. Therefore epilepsy should be suspected in children with autism who have paroxysmal events (Gabis L. et al., 2005).

The prevalence of epilepsy in autistic children has been estimated at 7 to $14 \%$, whereas the cumulative prevalence by adulthood is estimated at $20 \%$ to $35 \%$, seizures onset peaks in early childhood and again in adolescence. Mental retardation, with or without motor abnormalities and family history of epilepsy, was a significant risk factor for the development of seizures in autistic individuals (Gillberg C. and Steffenburg S., 1987; Tuchman R. et al., 1991; Wong V., 1993; Rapin I., 1996). 
In our study, there is higher prevalence of epilepsy than previous studies, and low functioning autistic cases were higher than high functioning cases as regard prevalence of epilepsy, and thus there is a correlation between autism and epilepsy and therefore the prognosis may be bad with presence of epilepsy, and this is in agreement with the result of the study of Rapin I., 1996.

In our study, epilepsy was higher than other previous studies because of parents in our country give more attention and sought medical advice urgently when there is epileptic seizures rather than the autistic features. The first group of symptoms noticed by the parents of the autistic children in the present study was the language defect in $(68.2 \%)$ of the cases. Language defects remain the focus of the parents even after diagnosis. Parents also tend to measure progress of treatment by the development of language. Language defects can be verbal or non verbal. In verbal defects, the child may have no spoken language or a few words that do not suit his/her chronological age or the child may have echolalia and other speech disorders. Non verbal language defects includes facial expressions and indicating wants using body parts, for example by pointing at a desired object, which is missing in most autistic children (Green $V$. et al., 2006).

Social reactivity defects were the first group of symptoms noticed by $(22.7 \%)$ of the parents of the autistic children in the current study. Social defects make the family of the autistic child suffer, because the child appears unable to recognize the caregivers, refuses to play or interact with people especially children prefers inanimate objects.In the present study, $(9.1 \%)$ of the autistic children showed behavioral defects (body rocking, television [T.V] watching and playing with objects for hours) as the first group of symptoms noticed by the parents who either consider them normal behaviors and over look them, or these behaviors irritate the parents so much that they train the children to stop them or to reduce their frequency.

Stereotyped movements are a particularly interesting set of motor behaviors prevalent in about one third of people with autism. A significant proportion of stereotyped movements in autism are also self-injurious behaviors (SIB), such as head banging. SIB is a devastating disorder, the prevalence of which in autism is estimated from 10-40 percent. Both SIB and stereotyped behavior are manifested at very early age, in normal infants, however, they rapidly decrease by one year and are rarely seen beyond five years of age (Schroeder S. et al., 2002).

In the present study, there is no statistically significant difference between the two groups of the autistic children as regard first observed symptom. According to the previous result, any child with language defect or delay in development of speech, autism should be considered. In the current study (8 cases out of 22) $36.4 \%$ of the autistic children were mild to moderate autism, (high functioning group) and (14 out of 22) 63.6\% were severe autism, or (low functioning group), the evaluation was by using Childhood Autism Rating Scale (CARS). CARS scores can be used for detection of severity of autism and follow up of the cases for evaluation of effect of treatment. Children with autism have a larger head circumference, only a small proportion have frank macrocephaly (Bolton P., et al., 1994; Bailey A. et al., 1995; Woodhouse W. et al., 1996) .

But in our study, number of cases below 5 years age was 5 only, and the number is so small to be compared with control group.

In the present study, there is no statistically significant difference between autistic and control groups as regard weight and height and this is in agreement with the result of the study of Hanan H., 2006. In the present study, the highly significant finding during the examination of autistic children was the presence of hyperactivity, $(95.45 \%)$ the autistic children were hyperactive $(\mathrm{P}<0.01)$. Problems of inattention and hyperactivity affect one half of individuals with autistic disorder. Care must be taken to ensure that inattention and hyperactivity are not manifestation of other behavioral pathology seen in association with autistic disorders, as this will affect treatment decisions (Hazell P., 2007).

The high incidence of hyperactivity in the autistic children of our study can be explained by, parents sought medical advice because of hyperactivity was a distressing problem in their families and causing scholastic inachievement.In the present study, the blood serotonin level was higher in autistic than control group, the plasma serotonin level was elevated in (31.8\%) of autistic children, and this is in agreement of the previous studies of (Anderson G. et al., 1990; Leventhal B. et al., 1990; Curraro M. et al., 1993; Leboyer M. et al., 1999; Chugani D., 2004; Muhle R., 2004; Cantor B., 2005).

In the present study, the blood serotonin level was higher in the low functioning group $(2.6 \pm 0.531)$ than high functioning group (2.5 \pm 0.8$)$, and there might be a relation between high plasma serotonin levels and lower verbal ability scores (Chugani D., 2004). Form the previous result, there is a possibility of correlation between high plasma serotonin level and severity of the disorder. Many studies have consistently reported that about onethird of autistic individuals have hyperserotonemia(Anderson G. et al., 1990). Persons with autism have high levels of serotonin-ranging between $25 \%$ and $50 \%$, higher than persons without autism, this higher serotonin level may result from problems with the serotonin transporter that arise from errors in the gene, high serotonin levels may explain why persons with autism have problems showing emotion and handling sensory information, such as sounds, touch and smells (Muhle R. et al., 2004, and Cantor B., 2005). 
Serotonergic abnormalities have been reported in autism, specifically hyperserotonemia, as well as elevated blood serotonin in the first-degree relatives of children with autism (Leboyer M. et al., 1999). Serotonergic abnormalities during prenatal and early postnatal development might lead to reciprocal changes in thalamocortical connectivity, which results in a certain predisposition for autism, hyperserotonemia in autism may also involve a typical metabolism of the metabolic serotonin precursor tryptophan as a potential mechanism for alterations in serotonin availability (Chugani D., 2004).

In the study of Cuccaro $M$. et al., (1993), they conducted a study that looked at the level of blood serotonin and the verbal ability of individuals with autism and their immediate relatives. Using a well accepted IQ test (Wechsler Scales), these researchers found that individuals with high serotonin platelet or blood levels, had lower verbal ability scores. However, other measurements of intellectual abilities were not changed, including visual-spatial ability or memory. In the study of (Hranilovic D. et al., 2006), hyperserotonemia is the most consistent serotonin- related finding in autism. The basis of this phenomenon, and its relationship to the central serotonergic dysfunction remains unclear.

Platelet serotonin level (PSL) in 53 autistic adults and 54 healthy controls was measured. Mean PSL in autistic group $(75.7 \pm 37.4 \mathrm{ng} / \mathrm{mul})$ was significantly higher than the control sample $(59.2 \pm 16.2 \mathrm{ng} / \mathrm{mul})$ due to apresence of hyperserotonemic subjects which comprised $32 \%$ of the patients. PSL of autistic subjects did not correlate with the severity of symptoms, as measured by total CARS score, or the degree of mental retardation. However, significant negative relationship was observed between PSL and speech development, indicating the relationship between the peripheral 5HT concentrations and verbal abilities in autistic subjects.

In the present study, fifteen cases out of $22(68.2 \%)$ of the autistic children had abnormal EEG findings, 5 cases from group 1 (high functioning autism) and 10 cases from group 2, and EEG interpretation was as the following, in group 1, three cases had focal epileptogenic discharges and mainly temporal, two cases had focal epileptic discharges with secondary generalization; in group 2, five cases had focal discharges and mainly temporal, three cases had focal with secondary generalization and two cases had generalized epileptic discharges. The result was statistically highly significant $(\mathrm{P}<0.01)$, and this in agreement with the previous studies of Toshiaki H. et al., (2001) and Chugani D. (2002).

Our study revealed 9 cases out of $15(60 \%)$ who had abnormal EEG findings were epileptics, and this is in agreement with the study of Rossi P. et al., (1995). EEG studies in autism, have revealed a high rate of epileptic EEG abnormalities, Small J., 1975 documented a relationship between EEG and IQ, in that the incidence of mental retardation was higher in the group with EEG abnormalities (Kawasaki Y. et al., 1997), reported that there was a significant relationship between the presence of epilepsy and the occurrence of spikes, although the focus of spike discharges has been reported to be the centro-temporal, temporal, or frontal region.

In an EEG study by Dawson G. et al., (1995) who compared the normally developing children with autistic children, they found EEG abnormalities in the frontal and temporal regions, but not in the parietal region, and that the differences were more prominent in the left than the Rt hemisphere, Harrison D. et al., 1998 presented an adult autistic patient with results suggestive of left anterior deactivation and right frontal activation.

From our mentioned results, this study pointed to a positive correlation between EEG with or without epilepsy and autism, as well as its severity.

In the present study, 3 cases (13.6\%) had structural MRI brain abnormalities in the form of white matter affection "posterior dysmyelination", but the result was statistically insignificant. In general, both CT and MRI data indicated an absence of gross structural brain lesions in autism spectrum disorders (Bailey A. et al., 1998).

As regard caudate measurements in autistic children, our study revealed that there was increased area of the caudate nucleus, "Rt more than Lt", the result was statistically significant in Rt caudate area. On the other hand, caudate measurements were increased in autistic children than in control group, but the result was statistically insignificant. As regard, intercaudate distance there was decrement in the autistic group than in the control group, but also, the result was statistically insignificant.

In the present study, there is increased frontal horn widths in autistic children, and the result was statistically significant $(\mathrm{P}<0.05)$. Also, this study revealed that there was increased measurement of inner table of clavrium, the result was statistically significant $(\mathrm{P}<0.05)$. This may agree with the study of Piven J. et al., (1996, 1997) on autistic children, by using volumetric MRI they found that there is increased volume of total brain, total tissue, lateral ventricle volumes, increased volume of parietal, temporal and occipital lobes. One MRI study of pair of MZ twins demonstrated decreased caudate, amygdale and hippocampus volumes as well as reduced volumes of the superior temporal gyrus and the frontal lobe relative to controls (Kates W. et al., 1998).

In the present study, decreased measurement of the corpus callosum in the autistic group than control group but the result was statistically insignificant. There was significance when comparing the length of corpus callosum and thickness of anterior part of corpus callosum in which decreased values in autistics than controls $(\mathrm{P}<0.05)$. The results agree with the results of Facundo $\mathbf{M}$. et al., (1999) in which the areas of corpus callosum were examind on midsagittal magnetic resonance imaging scans of 27 low-IQ autistic individuals and 17 non 
autistic individuals of comparable mental age, autistic individuals had a significantly smaller corpus callosum (most marked in the body). Result demonstrate that abnormalities of the corpus callosum reported in highfunctioning autistic individuals are also present in autistic individuals with mental retardation. This controversy of the increment or decrement of some parts of the brain may be related to the age of the patients or duration and severity of the autistic patients.

So, various anatomical sites in the brain have been hypothesized as the primary source of pathology in autistic disorder, such as enlarged brain size, reductions in the area of corpus callosum, and the medial temporal lobe structure. According to recent MRI studies, slow and differential maturation of the brain does not happen in autism. There is a relatively brief period of overgrowth, followed by reduced or arrested growth (Courchesne E., 2004).

\section{Conclusion}

- Language deficit is the first and the most common clinical presentation in autistic children.

- Autistic disorder is common in males than females.

- There are two apparent clinical types of autism, high and low functioning autism.

- Epilepsy and hyperactivity are a significant co-morbid conditions associated with autism.

- There is a positive correlation between epilepsy and severity of autism.

- There is high blood serotonin level in about one-third of autistic children with positive correlation between high serotonin level and severity of autistic features.

- Abnormal EEG finding is a significant result present in autistic children with a positive correlation between abnormal EEG findings and severity of autism.

- There are no specific structural brain MRI abnormalities in autism.

- There are differences in measurements of certain brain areas such as caudate and corpus callosum in autistic children and these differences can explain the autistic symptoms.

- There is a positive correlation between brain MRI measurement abnormalities and severity of autism

\section{From the present study, we can recommend the following:}

1. The pediatrician and neuropsychiatrist should give more attention to detect the early clinical manifestations of autism to minimize the social, communication and behavior abnormalities.

2. Screening and surveillance programs for early detection of autistic disorder.

3. Further study of serotonin levels in both blood and cerebrospinal fluid of autistic children and its effect on autistic symptoms.

4. Further study of volumetric MRI functional MRI, MRS and PET in autistic children.

\section{References}

[1]. Adrien J., Perrot A., Sauvage D. (1992): Early symptoms in autism from family home movies. Evaluation and comparison between $1^{\text {st }}$ and $2^{\text {nd }}$ year of life using I.B.S.E. scale. Acta. Pediatric psychiatry, 55:71-75.

[2]. American Psychiatric Association. (2000): Diagnostic and statistical manual of Mental Disorders. $4^{\text {th }}$ ed. TR Washington, DC.

[3]. Anderson G., Horne W., Chatterjee D., Cohen D. (1990): the hyperserotonemia of autism. Ann N. Y. Acad. Sci. 600(1):331-40.

[4]. Bailey A., Le Couteur A., Gottesman I., Bolton P., Simonoff E., Yuzda E., Rutter M. (1995): Autism as a strongly genetic disorder: evidence from a British twin study. Psychol Med., 25:63-77.

[5]. Bailey A., Phillips W., Rutter M. (1996): Autism: towards an integration of clinical, genetic, neuropsychological and neuro-biological perspectives. J. Child Psychol Psychiatry, 37: 89-126.

[6]. Bailey A., Luthert P., Dean A. (1998): A clinicopathological study of autism. Brain 121:889905.

[7]. Baron-Cohen S. (2002): The extreme male brain theory of autism, Trends in cognitive sciences, 6(6): 248-54.

[8]. Bertam C. and Hansom M. (2002): Prenatal programming of postnatal endocrine responses by glucocorticoids. Reproduction, 124: 459-67.

[9]. Bolton P., Macdonald H., Pickles A. (1994): Acase-control family history study of autism. J. child. Psychol Psychiatry, 35:877-900.

[10]. Cantor B. (2005): Replication of autism linkage: fine mapping peak at 17q21. American Journal of Human Genetic, 76: 1050-56.

[11]. Chugani D. (2002): Role of altered brain serotonin mechanisms in autism, Mol. Psychiatry; 7 Supp 2:16-27. 
[12]. Chugani D. (2004): Serotonin in autism and pediatric epilepsies. Mental Retardation and Developmental Disabilities Research Reviews, 10:112-16. [Cross Ref.] [Medline].

[13]. Courchesne E.(2002): Abnormal early brain development in autism. Molecular psychiatry, 7 (suppl.z), S21-23. [Cross Ref.]. [Medline]

[14]. Cuccaro M., Wright H., Abramson R., Marsteller F., Valentine J. (1993): Whole blood serotonin and cognitive functioning in autistic individuals and their first-degree relatives. $\mathbf{J}$ Neuropsychiatry ClinNeurosci. 5:94-101.

[15]. Daley T. (2004): From symptom recognition to diagnosis: Children with autism in urban India. Social Science and Medicine, 58:1323-35.

[16]. Dawson G., Klinger L., Panagiotides H., Lewy A., Castelloe P. (1995): Subgroups of autistic children based on social behavior display distinct patterns of brain activity. J. Abnormal Child Psychol 23: 569-83.

[17]. DeGiacomo A. and Fombonne E. (1998): Parental recognition of developmental abnormalities in autism. European child and Adolescent Psychiatry, 7(3): 131-6.

[18]. Facundo M., Joseph P., Daniela V., Valeria N., Christian P., Sergio E. (1999): An MRI study of the corpus callosum and cerebellum in mentally retarded autistic individuals.the journal of Neuropsychiatry and clinical neurosciences, 11:470-74.

[19]. Filipek P., Accordo P., Baranek G., Cook E., Dawson G., Gordon B. (1999): The screening and diagnosis of autistic spectrum disorders. J. Autism Dev. Disord., 29:439-84.

[20]. FolsteinS.and Rosen- Sheidley B. (2001): Genetics of autism: complex aetiology for a heterogeneous disorder.Nat Rev. Gent., 2:943-55.

[21]. Fombonne E. (1999): The epidemiology of autism: a review. Psychol Med., 29(4): 769-86.

[22]. Fombonne E. (2003): The prevalence of autism. JAMA, 289:87-9.

[23]. Gabis L., Pomeroy J., Andriola M. (2005): Autism and epilepsy: cause, consequence, comorbidity, or coincidence? Epilepsy Behav. 7 (4): 652-6.

[24]. Germano E., Gagliano A., Magazu A., Calarese T., Calabro M., Bonsignore M., Tortorella G., Calamoneri F., (2006): Neurobiology of autism: study of a sample of autistic children, Minerva Pediatr.58(2); 109-20.

[25]. Gillberg C. (1998): Chromosomal disorders and autism. J. Autism. Dev. Disord., 28:415-25.

[26]. Gillberg C. and Coleman M. (2000): The Biology of the autistic syndromes. $3^{\text {rd }}$ ed. London, UK: Mac Keith Press, Distributed by Cambridge University Press.

[27]. Gillberg C. and Steffenburg S. (1987): Outcome and prognostic factors in infantile autism and similar conditions: a population- based study of 46 cases followed through puberty. J. Autism Dev. Disord., 17:273-287.

[28]. Green V., Pituch K., Itchon J., Choi A., O'Reilly M., Sigafoos J. (2006): Internet survey of treatments used by parents of children with autism, Research in Developmental Disabilities. 27:70-84

[29]. Hanan H. (2006): Study of serum level of some trace elements in children with autistic disorders. Thesis submitted for Msc. Degree in pediatrics. Faculty of medicine, Alexandria University, Egypt.

[30]. Harrison D., Demaree H., Shenal B., Everhart D. (1998): QEEG assisted neuropsychiological evaluation of autism. Intern J. neuroscience 93:133-40.

[31]. Hazell P. (2007): Drug therapy for attention-deficit/ hyperactivity disorder-like symptoms in autistic disorder. J. Paediatr Child Health, 43(1-2): 19-24.

[32]. Hranilovic D., Bujas-Petkovic Z., Vragovic R., Vuk T., Hock K., Jernej B. (2006):Hyperserotonemia in adults with autistic disorder. J. Autism dev. Disord. 5(1):94-101.

[33]. Kates W., Mostofsky S., Zimmerman S. (1998): Neuroanatomical and neurocognitive differences in a pair of monozygous twins discordant for strictly defined autism. Ann Neurol., 43:782-91.

[34]. Kawasaki Y., Yokota K., Shinomiya M., Shimizu Y., Naiwa S. (1997): Brief report: electroencephalographic paroxysmal activites in the frontal area emerged in middle childhood and during adolescence in a follow- up study of autism. J. Aut. Dev. Disord. 27:605-20.

[35]. Larson H., Eaton W., Madsen K., Vestergaard M., Olesen A., Agerbo E., Schendel D. (2005): Risk Factors for Autism: perinatal factors, parental psychiatric history, and socioeconomic status. Am J. Epidemiol., 161:916-25.

[36]. Leboyer M., Philippe A., Bouvard M., Bataille M., Bondoux D., Tabuteau F., Feingold J., Simeoni M., Launay J. (1999): Whole blood serotonin and plasma beta- endorphin in autistic probands and their first- degree relatives. Biological psychiatry, 45(2):158-163. 
[37]. Leventhal B., Cook E., Morford M., Ravitz A., Freedman D. (1990): Relationships of whole blood serotonin and plasma norepinephrine within families.Journal of Autism and Developmental Disorders, 20(4):499-511.

[38]. Liu J., Nyholt D., Magnussen P., Parano E., Pavone P., Geschwind D. (2001): A genome wide screen for autism susceptibility loci. Am. J. Hum. Genet., 69:327-40.

[39]. Lord C., Rutter M., Le Couteur A. (1994): Autism Diagnostic Interview- Revised: A revised version of a diagnostic interview for caregivers of individuals with possible pervasive developmental disorder. Journal of Autism and Developmental Disorder, 24:659-85.

[40]. Muhle R., Hyman S., Stodgell C. (2004): The Genetics of Autism. Pediatrics, 113(5): 472-86.

[41]. Osterling J. and Dawson G. (1994): Early recognition of children with autism: a study of first birthday home videotapes. J. Autism Dev. Disord., 24:247-57.

[42]. Piven J., Arndt S., Bailey J., Andreasen N. (1996): Regional brain enlargement in autism: a magnetic resonance imaging study. J. Am Acad child adolesc psychiatry, 35:530-36.

[43]. Piven J., Bailey A., Ranson B. (1997): An MRI study of the corpus callosum in autism. Am.J. Psychiatry. 154:1051-56.

[44]. Rapin I. (1996): Historical data. In: Rapin I., ed. Preschool language disorder, autism, low IQ. London, Uk: mac lceith press: 58-97.

[45]. Rossi P., Parmeggiani A., bach V, Santucci M., Visconti P. (1995): EEG features and epilepsy in patients with autism. Brain 17:605-620.

[46]. Rutter M. (2005):Aetiology of autism. Findings and questions. J. IntellecDisabil. Res. 49(pt 4): 231-8 (Medline) .

[47]. Rutter M. (2005): Incidence of autism spectrum disordes: changes over time and their meaning. Actapaediatr. 94(1): 2-15.

[48]. Salmond H., de Haan M., Fristonic J. (2003): Investigating individual differences in brain abnormalities in autism. Philo trans RSOC long B Biol. Sci., 358(1430): 405-13 (Medline).

[49]. Schroeder S., Oster-Granite M., Thompson T. (2002): Self- injurious Behavior. Gene-brainbehavior Relationships. Washington, DC: APA Books.

[50]. Shao Y., Wolpert C., Raiford K. (2002): Genomic screen and follow-up analysis for autistic disorder. Am. J. Med. Genet., 114:99-105.

[51]. Siegel B., Pliner C., Eschler J., Elliott G. (1998): How children with autism are diagnosed: difficulties in indentification of children with multiple developmental delays. Developmental and Behavioral pediatrics, 9(4): 199-204.

[52]. Toshiaki H., Masayuki S., Kenji S., Shigeru H., Michio F. (2001): Paroxysmal discharges on EEG in young autistic patients are frequent in frontal regions. J. Med. Invest. 48:175-180.

[53]. Tuchman R., Rapin I., Shinnar S. (1991): Autistic and dysphasic children. II. Epilepsy. Pediatrics, 88:1219-25.

[54]. Volkmar F., Stier D., Cohen D. (1985): Age of recognition of pervasive developmental disorder. American Journal of psychiatry, 142(12): 1450-2.

[55]. Wong V. (1993): Epilepsy in children with autistic spectrum disorder. J. child Neurol., 8: 316 22.

[56]. Woodhouse W., Bailey A., Rutter M., Bolton P., Baird G., Le Couteur A. (1996): Head circumference in autism and other pervasive developmental disorders. J. Child Psychol Psychiatry, 37:665-71.

[57]. Yeargin- Allsopp M., Rice C., Karapurkar T., Doernberg N., Boyle C., Murphy C. (2003): Prevalence of autism in aUS metropolitan area. JAMA, 289:49-55.

[58]. Zilbovicius M., Meresse I., Boddaert N. (2006): Autism Neuroimaging, Rev Bars Psiquiatr, 28 suppl. 1:5,21-8. 
إضطر ابات النمو النمطية المنتشرة حديثاً هى مجمو عة من الأمر اض تتميز بعيوب فى اللغة، و التو اصل الاجتماعي وتكر ار السلوك و العادات بصورة نمطية.

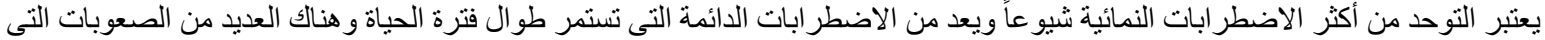

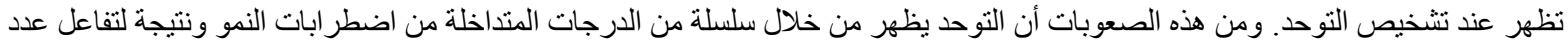

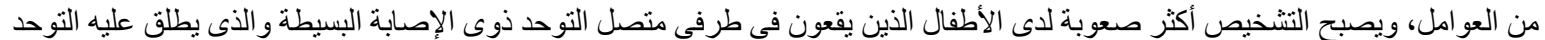

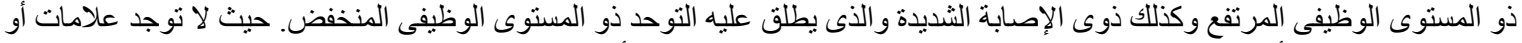

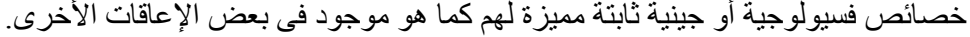

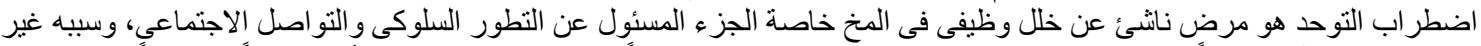

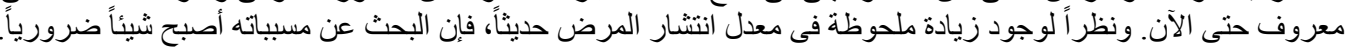

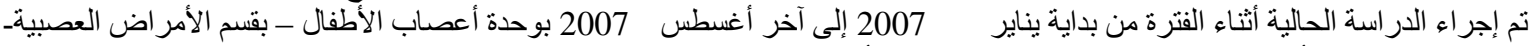

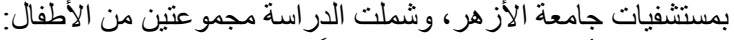

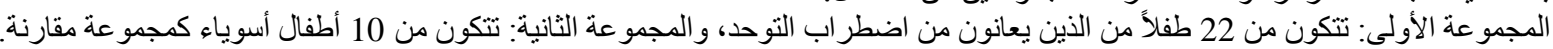
تم تشخيص الحالات عن طريق تطبيق العلامات الفارقة لمرض من التوحد باستخدام الدليل الإحصائى التشخيصى الر ابع النسخة المر اجعة لعام 2000.

$$
\text { وتشمل خصائص الانضمام على: }
$$
عدم وجود خلل كبير بالمخ عن طريق التئ التصوير بالرنين المغناطيسى.

الأطفال المصابون بالاضطر ابات الات الارتقائية المصنفة مثل اضطر اب ريت.

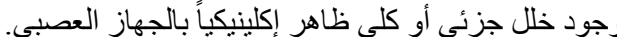
الأطفال المصابون بأمر اض كلى عضوية مزمنة مثل أمر اض اضلى الصدر أو ضغط الدام.

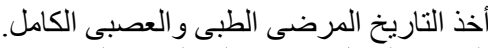
الفحص الكامل خاصنة على الجهاز العصبى و النعلى النفسى.

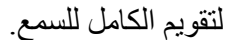

مقياس تقدير التوحد فى مرحلة الطفولة (اختبار كارز).

$$
\text { وباستخدام هذا الاختبار تم تقسيم الحالات إلى مجلى مجمو عنين: }
$$

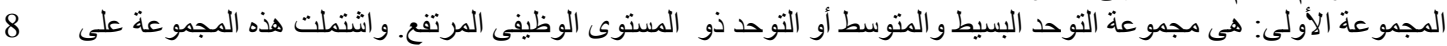

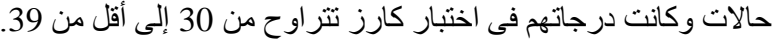

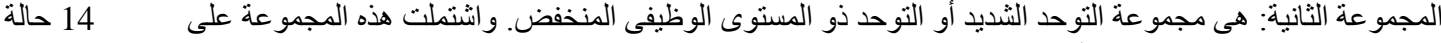

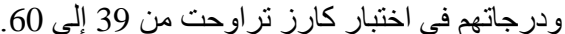

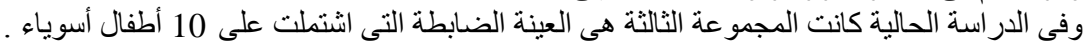

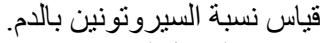

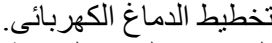

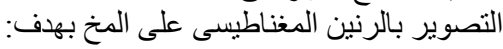

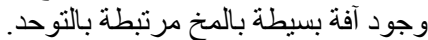

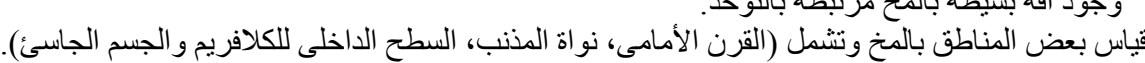

بلغت نسبة زواج الأقارب في (22.27٪) من حالات التوحد، ووجد أفر اد آخرون مصابون بالتوحد في العائلة فى (9٪) من الحالات. 


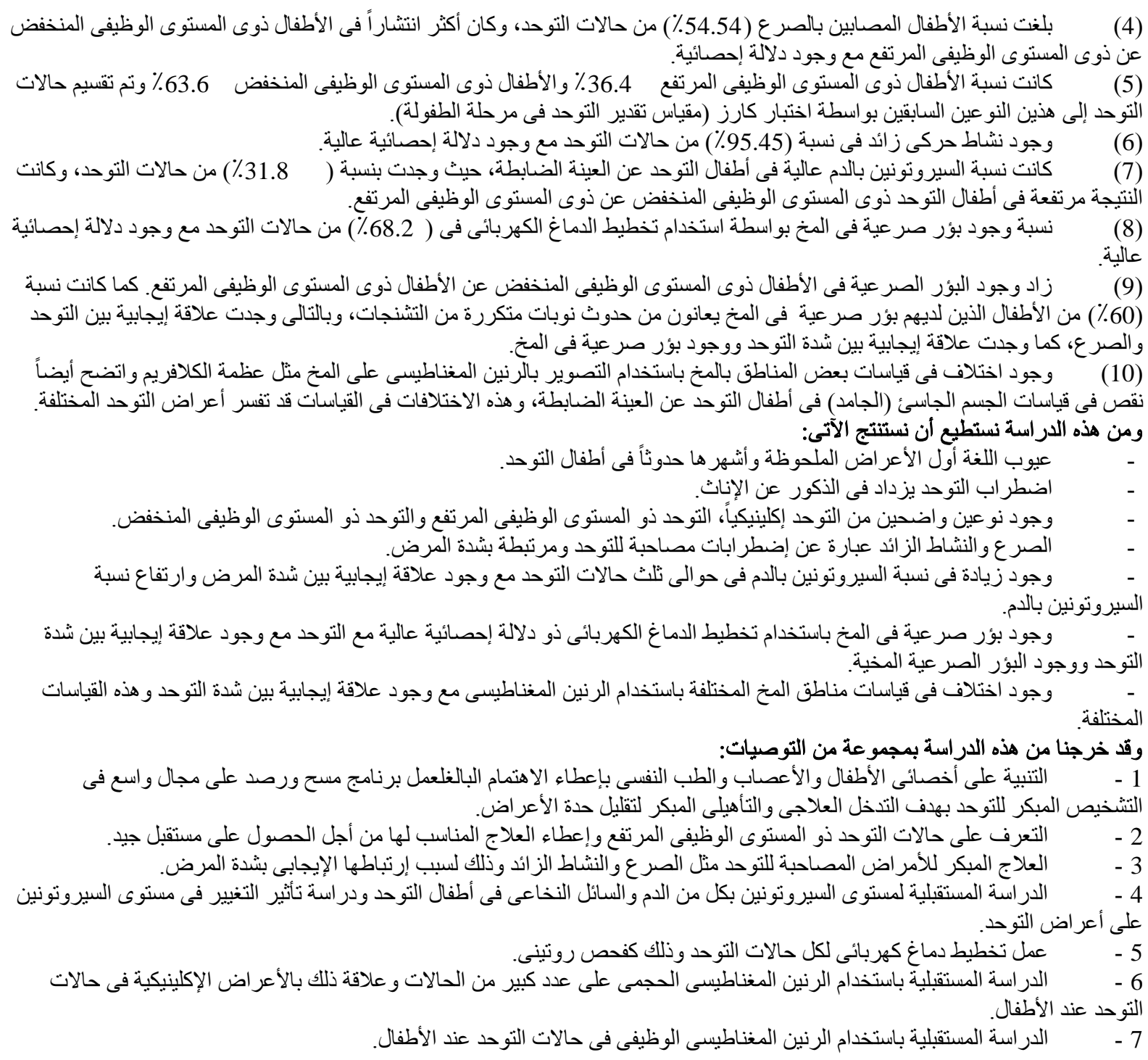

